Niina Oisalo

M.A., YTM, mediatutkimus, Turun yliopisto

\title{
KATJA GAURILOFF:
}

"Voimme vihdoin kertoa omalla kielellämme ja elokuvan kielellä omia tarinoitamme saamelaisuudesta"

Elokuvantekijä Katja Gauriloff on äitinsä puolelta kolttasaamelainen. Etelän vuosien jälkeen hän on palannut pohjoiseen, lähemmäs saamelaisyhteisöä. Myös elokuva on tuonut Gauriloffin uudella tavalla kosketuksiin oman kulttuurin kanssa. "Tarpeesta kertoa omia tarinoitani kolttasaamelaisesta perinteestä on syntynyt pitkä ja syvällinen prosessi - elämänmittainen ja kulttuurinkokoinen asia", hän sanoo Lähikuvan haastattelussa.

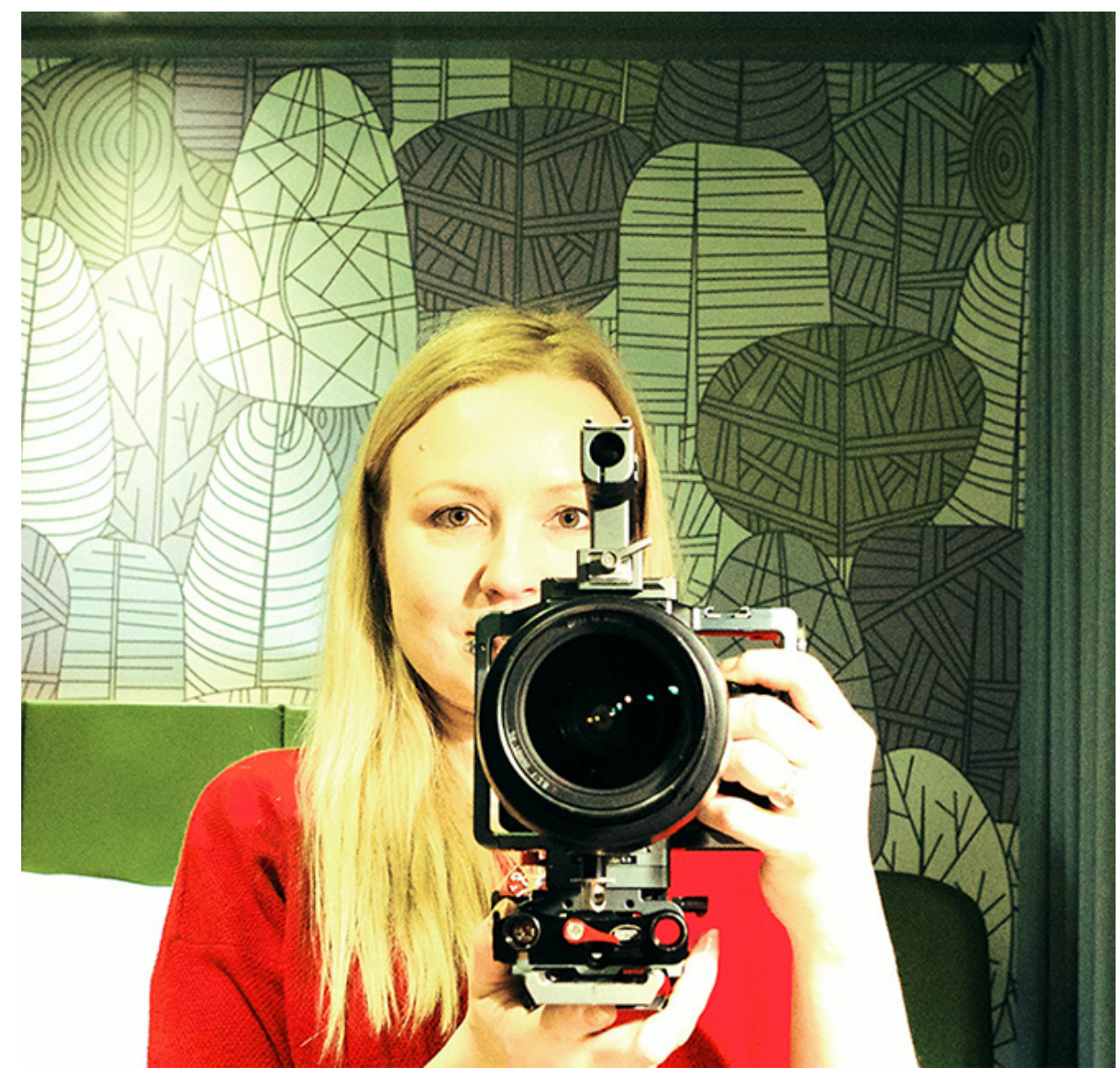

Koska haastattelu tehtiin etäyhteyksin, Katja Gauriloff lähetti meille omakuvan. 
Katja Gauriloffin ura elokuvantekijänä alkoi vuonna 2004, jolloin hän oli mukana perustamassa Oktober-tuotantoyhtiötä. Sen jälkeen Gauriloff on ohjannut pääosin dokumenttielokuvia, mutta myös yhden fiktion, ja toinen on tekeillä. Hänen dokumenttielokuvansakin leikittelevät fiktiivisillä elementeillä, eikä Gauriloff itse näe dokumentti- ja fiktioelokuvan eroa lopulta niin suurena, paitsi tuotantomielessä.

Esikoiselokuva oli seurantadokumentaari Huuto tuuleen (2007, Suomi), joka syntyi Gauriloffin vielä opiskellessa elokuvakoulussa. Siinä ohjaaja palasi sukunsa maille Sevettijärvelle ja seurasi ihmisten arkea ilman saamelaisiin liitettyjä kliseitä - nuoren naisen elämää, jossa kaipuu etelän kaupunkeihin sekä rakkaus kotiseutuun ja omaan yhteisöön vuorottelivat, ja kolttasaamelaisen poliitikon kamppailuja yhteisönsä elinehtojen puolesta.

Kokopitkä dokumenttielokuva Säilöttyjä unelmia (Canned dreams, 2012, Suomi, Irlanti, Norja, Portugali, Tanska) oli hänen uransa läpimurto, suuri kansainvälinen tuotanto, joka menestyi myös kansainvälisillä festivaaleilla. Rakenteeltaan episodimaisessa elokuvassa seurataan ravioli-säilykepurkin ainesosien valmistusta kymmenessä eri maassa, kuten brasilialaisella kaivoksella, tanskalaisella sikatilalla ja puolalaisella teurastamolla, ja purkin matkaa suomalaiseen automarkettiin.

Kolttasaamelaisen kulttuurin äärelle toi Kuun metsän Kaisa (2016, Suomi), joka kertoo Gauriloffin isoisoäidistä Kaisa Gauriloffista ja tämän ystävästä, sveitsiläisestä kirjailijasta Robert Crottet'sta. Elokuva on unenomainen matka Crottet'n ja Gauriloffin elämäntarinoihin, uniin ja kuvitelmiin. Kuun metsän Kaisa palkittiin vuoden 2016 parhaan dokumenttielokuvan Jussi-palkinnolla, se sai Murmanskissa Northern Character -elokuvafestivaalien Grand Prix -pääpalkinnon ja Leipzigin Golden Dove -pääpalkinnon parhaana animoituna dokumenttielokuvana.

Ensimmäinen pitkä fiktio Baby Jane valmistui 2019. Elokuva perustuu Sofi Oksasen samannimiseen romaaniin, joka kertoo kahden naisen välisestä intensiivisestä rakkaussuhteesta. Päärooleja siinä näyttelevät Roosa Söderholm, Maria Ylipää ja Lauri Tilkanen.

Juuri nyt tekeillä on Gauriloffin toinen fiktioelokuva, kolttasaamelaisen tytön kasvukertomus Je'vida. Elokuva pohjautuu sekä Gauriloffin oman suvun että muiden saamelaisten kokemuksiin ja kertoo juurille paluusta pitkän poissaolon jälkeen. Elokuvasta on tarkoitus tulla koltan- ja suomenkielinen.

Gauriloff muutti kahdeksan vuotta sitten Etelä-Suomesta takaisin pohjoiseen ja viettää aikansa nyt Rovaniemen ja Utsjoen kodeissa. Muutto toi tekemiseen tervetullutta rauhaa, ja matkustelu useiden maiden välillä vaihtui satunnaisiin käynteihin Helsingissä.

\section{Niina Oisalo:}

Millaista on ollut työskennellä elokuvantekijänä pohjoisessa?

\section{Katja Gauriloff:}

Olin pohjoiseen muuttaessa jo aika kypsynyt matkustamiseen Suomen ulkopuolella. Aluksi se oli tietysti hauskaa, mutta kävi pidemmän päälle raskaaksi. Kun elokuvanteko on kuumimmillaan, niin se vaatii edelleen Helsingissä matkustamista, mutta pääosin arki on rauhallisempaa.

Täällä saa vain olla ja kirjoittaa, ja tuotannot etenevät siinä missä Helsingissäkin asuessa. Pohjoisessa on syntynyt myös ihan uudenlaisia projekteja, joita minulle ei olisi tullut mieleen toteuttaa, jos asuisin vielä etelässä. Olen myös löytänyt uudenlaisia näkökulmia, ja miettinyt enemmän oman kansani asioita, vaikka kaikenlaisia muitakin aiheita pyörii kyllä edelleen mielessä.

Elän nyt kolmivuotisella taitelija-apurahalla, mikä on auttanut todella paljon, muuten olisi vaikea tulla toimeen elokuvantekijänä. Helsingissä tein esimerkiksi 
mainos- ja tilaustöitä sekä opettamista elokuvanteon ohessa, mutta täällä pohjoisessa olen elänyt keskittyneempää ja hitaampaa elämää.

Olemme saaneet vietyä tuotantoja eteenpäin koronapandemian aikanakin, vaikka taustatutkimusmatka Sevettijärvelle ja muualle lykkääntyi, kun kohtaamiset eivät nyt ole mahdollisia (toim. huom. haastattelu tehtiin huhtikuussa). Mutta toivottavasti jo kesän aikana pääsemme käymään siellä.

Kerro tulevasta, Je'vida-työnimellä kulkevasta elokuvastasi - mistä siinä on kyse?

Je'vida kertoo kolttatytön elämästä kolmella eri vuosikymmenellä: 10-vuotiaana lapsena 1950-luvulla, 20-vuotiaana aikuisena 1960-luvulla ja vanhana naisena nykyajassa. Elokuvan teema on kotiinpaluu, omille juurilleen paluu. Se kertoo oman kulttuurin siirtämisen tarpeesta, muistista ja muistamisesta.

Rakenteellisesti elokuvassa on kolme aikatasoa, jotka tapahtuvat yhtä aikaa, limittäin. Tällaista rakennetta on ollut todella hauska kirjoittaa ja suunnitella.

Olemme tehneet käsikirjoitusta reilun vuoden yhdessä Niillas Holmbergin kanssa, ja toinen käsikirjoitusversio on juuri valmistunut. Olemme saaneet jo joitain kehittelytukia, joten seuraavaksi olisi tarkoitus tehdä näyttelijävalintoja. Koska elokuva on suurelta osin koltansaamenkielinen, tulee olemaan haasteellista löytää erityisesti lapsinäyttelijöitä, sillä kolttasaamen puhujia on edelleen hyvin vähän. Siitäkin huolimatta, että kielen elvytys on tepsinyt, ja uuden sukupolven myötä puhujia on tullut lisää. Lapsia, jotka puhuvat kolttaa, on kuitenkin käytännössä vain muutama.

Kuvauspaikkoja etsimme kolttasaamelaisten asuinpaikoilla, Sevettijärven ympäristössä.

\section{Miten idea elokuvaan syntyi?}

Aihe on pyörinyt kauan mielessäni, oikeastaan koko elämäni on ollut materiaalinkeruuta tätä elokuvaa varten. Olen kuullut lapsesta asti tarinoita ja tarinan pätkiä, jotka ovat tulleet tavalla tai toisella elokuvaan.

Tärkeä oli myös 15 vuotta sitten tapahtunut kohtaaminen. Olin silloin vielä opiskelija ja päätin liftata Inarista Sevettijärvelle. Sain kyydin kolttasaamelaiselta mieheltä. Oli talvinen aamu, vielä pimeää, kun lähdimme ajamaan Inarista. Yhtäkkiä mies kääntyi sivutielle ja alkoi kertomaan minulle tarinaa, omaa syntymätarinaansa. Tuo kohtaaminen ja hänen kertomuksensa jättivät minuun todella syvän jäljen, ja löysivät myös tiensä Je'vidaan.

Hieman kuten Kuun metsän Kaisassa, Je'vidassa häilytään realismin ja "korotetun realismin" välillä - siinä on esimerkiksi tytön keskusteluja kuolleen isoisänsä kanssa. Je'vida onkin eräänlainen jatkumo Kuun metsän Kaisalle, mutta fiktiivinen sellainen - elokuva jatkaa siitä historiallisesta hetkestä johon Kuun metsän Kaisa jäi, eli 1950-luvulta, jolloin koltat oli asutettu sodan jälkeen nykyisille sijoilleen (toim. huom. aiemmat asuinsijat jäivät rajan taakse Venäjälle).

Olet ohjannut myös aiemmin hyvin henkilökohtaisia tarinoita, erityisesti Kuun metsän Kaisan. Miten olet päätynyt käsittelemään kolttasaamelaisuutta elokuvissasi?

Vaikka olenkin asunut lapsuuteni "etelässä" Rovaniemellä, elimme perheen kanssa niin saamelaisesti kuin mahdollista ja vietimme myös paljon aikaa Saamenmaalla kalastellen tai hillametässä. Lapsuudessa kuulemistani asioista ne tarinani ovat osin kummunneet. Pakkosuomalaistamisesta johtuen en kuitenkaan oppinut koltankieltä äidiltäni, vaikka hän on puhunut sitä sisarustensa tai vanhempien ihmisten kanssa. Elokuva on tuonut minut lähemmäksi yhteisöä, joka katosi elämästäni lapsuuden jälkeen, kun muutin itse etelämmäs. 
Kolttasaamelaisille juurille paluuni alkoi oikeastaan jo opiskeluaikana, kun ohjasin Huuto tuuleen -elokuvan. Mutta Kuun metsän Kaisa on ehdottomasti ollut tärkein työni - sekä henkilökohtaisesti että laajemmasta näkökulmasta.

Kaiken kaikkiaan tarve kertoa omia tarinoitani kolttasaamelaisesta perinteestä on ollut pitkä ja syvällinen prosessi - elämänmittainen ja kulttuurinkokoinen asia.

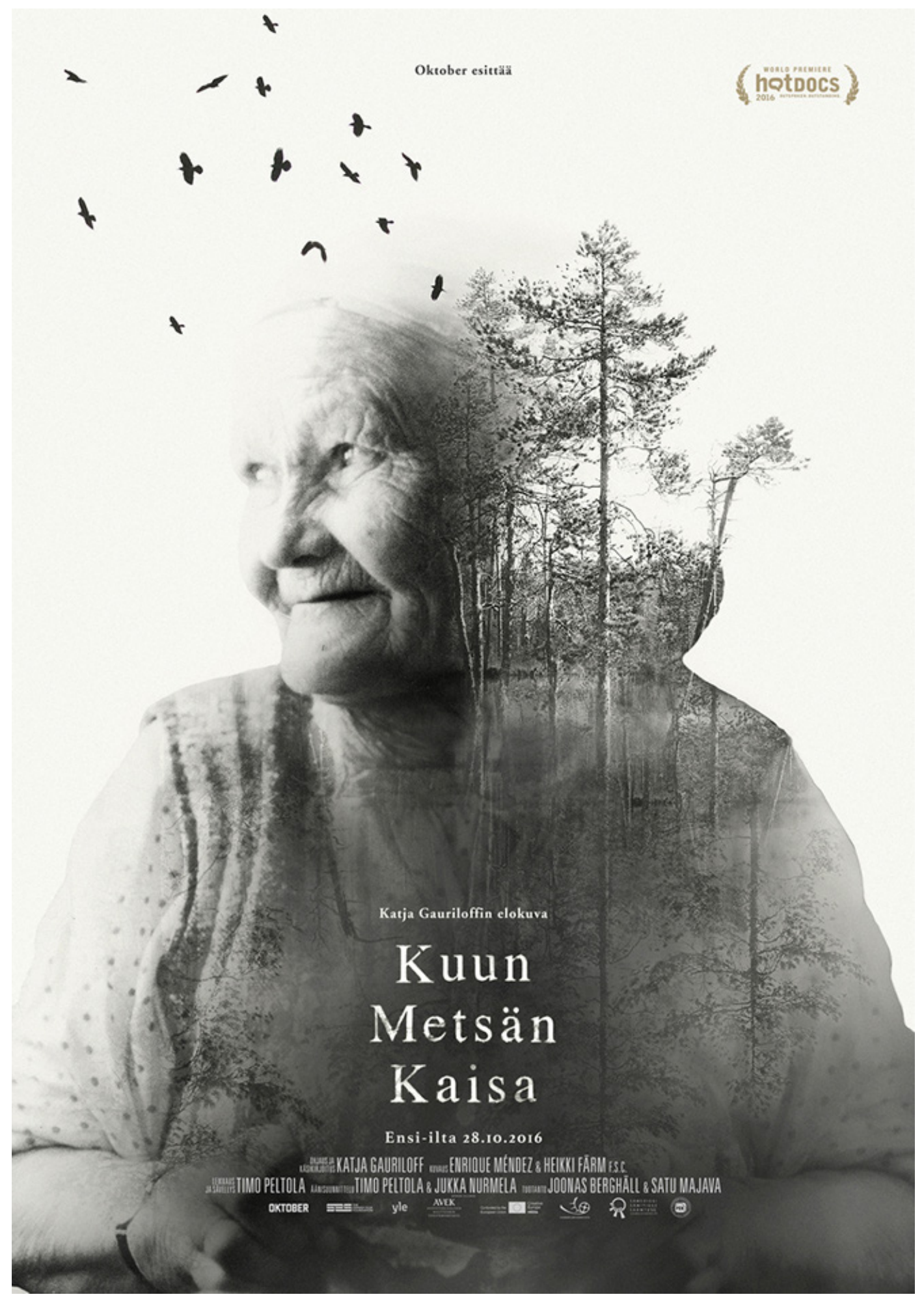

Kuun metsän Kaisa (2016) on ollut Katja Gauriloffin tähänastisen uran merkittävin työ sekä henkilökohtaisesti että kolttasaamelaisen yhteisön kannalta. Kuva: Oktober Oy. 


\section{Millainen prosessi Kuun metsän Kaisan tekeminen oli sinulle?}

Se että sain kerrottua isoisoäidin tarinan, oli erityistä sekä minulle ja perheelleni että kolttasaamelaiselle yhteisölle. On tärkeää, että näitä tarinoita ei unohdeta. Projekti oli myös tärkeä minulle ohjaajana, sillä sain tehdä taiteellisesti juuri sellaisen elokuvan kuin halusin. Elokuva oli siten hyvin merkityksellinen paitsi henkilökohtaisella tasolla myös saamen kansan ja kolttasaamelaisen yhteisön näkökulmasta.

Olen saanut elokuvasta todella hyvää palautetta saamelaiselta yhteisöltä. Yleisö on kiittänyt tämän tarinan kertomisesta, mutta myös tavasta, jolla se kerrottiin, hieman sadunomaisesti. Yleensä meidän tarinoitamme on kerrottu ulkopuolelta, ulkopuolisten silmin - mutta tätä tarinaa ei olisi voinut kukaan ulkopuolinen kertoa, ainakaan tällä tavalla.

Kuun metsän Kaisa kiersi paljon maailmalla, mutta minä en niinkään - ja sitä pyydetään edelleen esitettäväksi todella paljon. Minä käyn myös edelleen puhumassa siitä, viimeksi Oulun Giellagas-instituutissa. Kuun metsän Kaisa tuntuu myös kiinnostavan tutkijoita, ja sillä on paljon faneja, jotka ovat nähneet elokuvan monta kertaa ja löytävät siitä aina jotain uutta.

Entä miltä tuntui siirtyminen dokumenteista fiktioon - millä tavoin Baby Janen (2019) ohjaustyö erosi aiemmista dokumenttiprojekteistasi? Miten koet ylipäätään fiktion ja dokumenttielokuvan välisen rajankäynnin?

Se oli hieno projekti, oli upeaa saada tehdä töitä suuren ryhmän kanssa, ja budjetti oli tietenkin suurempi. Fiktioissa ja dokumenttielokuvissa on molemmissa puolensa.

Dokumentaristina saa ainakin minun kokemukseni mukaan olla vapaampi ja tehdä mitä haluaa, mutta budjetit ovat usein pienempiä. Fiktion tekemisessä taas on täysin sidottu käsikirjoitukseen, mutta etenkin työskentely kuvauksissa on todella hienoa - että saa tehdä yhteistyötä näyttelijöiden ja muiden taiteenalojen, kuten lavastuksen ja puvustuksen, ihmisten kanssa.

En tosin tiedä, ovatko dokumenttielokuvanikaan olleet täysiverisiä dokkareita, sillä olen käyttänyt niissä paljon fiktiivisiä elementtejä. Pelkästään kameran läsnäolo tilanteissa saattaa muuttaa ihmisten käyttäytymistä, sillä on sähköistävä vaikutus. Jo Huuto tuuleen -elokuvaa tehdessä huomasin, miten kamera muokkaa todellisuutta ja saa tapahtumaan kaikenlaisia asioita, joita ei muuten ehkä tapahtuisi.

Kuten dokumenttielokuva, myös fiktio lähtee jostain havainnosta tosielämästä, ja tämä havainto voi olla hyvin lähellä ja hyvin kipeä. Fiktio- ja dokumenttielokuvat voivat siten olla tekijälle prosesseina hyvin samankaltaisia.

\section{Miltä saamelaisen elokuvan tilanne näyttää sinusta tällä hetkellä?}

Vaikuttaa siltä, että saamelaisella elokuvalla on pääosin hyvä tilanne. Kentällä on vakiintuneita tekijöitä ja uusia kouluttautuu alalle. Saamelaiselokuva on vakiinnuttanut paikkansa elokuva-alalla.

Nykyään elokuvaa pidetään johtavana saamelaistaiteen alana - näin on sanonut professori Veli-Pekka Lehtola Oulun yliopiston Giellagas-instituutista.

Pohjoismaista löytyy ohjaajia, jotka käsikirjoittavat pääasiassa itse elokuvansa, mutta tuottajia puuttuu. Suomessa ei taida tällä hetkellä olla yhtään saamelaista tuottajaa, ja myös muita elokuvan ammattilaisia on vähän.

Rahoituksen saaminen on edelleen vaikeaa saamelaisille elokuvantekijöille, sillä rahoittajat näkevät saamelaiselokuvan omana genrenään ja antavat tukea keskimäärin yhdelle saamelaiselle elokuvantekijälle kahden vuoden välein. Rahoittajat eivät pysty näkemään, että saamelaisten keskuudessa on erilaisia tekijöitä ja projekteja, eivätkä kaikki "saamelaiselokuvat" ole samanlaisia. 
Onneksi on myös muita rahoittajia, kuten ISFI (International Sámi Film Institute), joka on auttanut etenkin uusia tekijöitä. ISFI on ollut todella merkittävä taustatekijä saamelaisen elokuvan kehityksen kannalta. Sitä kautta saamelaiset elokuvantekijät ovat voineet olla yhteydessä myös muihin alkuperäiskansojen tekijöihin, kuten Pohjois-Amerikan alkuperäiskansoihin ja maoreihin. Instituutti järjestää isoja konferensseja, jotka ovat olleet hyvin voimauttavia tilaisuuksia - instituutti ei siten tarjoa pelkästään rahallista tukea, vaan yhteisön tukea. Sitä kautta on mahdollista saada myös dramaturgista apua tuotantoihin ja elokuva-alan koulutusta.

Haluan myös itse tukea uusia saamelaiselokuvantekijöitä. Teimme juuri Niillas Holmbergin kanssa musiikkivideon (https://www.youtube.com/ watch? $v=J 9 P d W n p x M y M)$, johon halusin saamelaisen nuoren naisen, Lada Suomenrinteen, kuvaajaksi. Tuottajien olisi hyvä muistaa, että alalla on muitakin tekijöitä kuin ne vanhat tutut, ja näillä muilla voi olla tuoreita näkökulmia.

\section{Miten saamelaisen elokuvan näkyvyyttä voisi vielä parantaa?}

Esityspaikkoja voisi olla enemmän, sillä se tarkoittaisi myös suurempia budjetteja elokuville.

Suomessa olen saanut elokuvilleni esitysaikaa esimerkiksi Ylellä ja jopa teatterilevityksen kahdelle pitkälle dokumenttielokuvalle, Kuun metsän Kaisalle ja Säilötyille unelmille, mutta Suomen ulkopuolella on ollut vaikeampaa. Esimerkiksi pohjoismaiset tv-kanavat tuntuvat tykkäävän enemmän feelgood-elokuvista kuin, ainakaan tietynlaisista, dokkareista. Kuun metsän Kaisalle oli hankala saada levitystä - ehkä hidasta, mustavalkoista, historiallista dokumenttielokuvaa ei koettu ohjelmapolitiikkaan sopivaksi.

Yhteistuotantoja pohjoismaisten kanavien kanssa on ollut vaikea saada. Olen kuullut torjunnan syyksi esimerkiksi sen, "kun meillä on nämä omatkin saamelaiset". Eli taustalla voi olla hieman samantapaista ajattelua kuin suomalaisilla rahoittajilla kaikki saamelaiset tekevät samankaltaisia elokuvia, ja siksi vain yksi saamelaistekijä kerrallaan voi saada rahoitusta.

Tietenkin saamelaisten omilla elokuva-alan organisaatioilla, kuten ISFI:llä ja Skábmagovat-elokuvafestivaaleilla on ollut tärkeä rooli saamelaisen elokuvan nostamisessa. Skábmagovat on tällä hetkellä itse asiassa ainoa saamelaiselokuvan festivaali, ja siksi toivoisin, että se voisi kasvattaa rooliaan myös tekijöiden nostamisessa. Festivaalin yhteydessä voisi olla vielä enemmän esimerkiksi pitchaus-tilaisuuksia, joissa saamelaistekijöiden olisi mahdollista luoda kontakteja rahoittajiin. Viime vuonna tämän tyyppisiä tilaisuuksia jo olikin.

\section{Miltä saamelaisen elokuvan tulevaisuus näyttää?}

Haluan ajatella, että valoisalta. Meillä on paljon kertomattomia tarinoita, ja elokuvantekijöille on suuri tilaus saamelaisessa yhteisössä. On upeaa, että voimme vihdoin kertoa omia tarinoitamme omalla kielellämme ja elokuvan kielellä.

Elokuva sopii minun mielestäni hirveän hyvin saamelaisten tarinoiden välittämiseen. Saamelaisen kulttuurin perinnettä on välitetty aina suullisesti, ja elokuvakerronnassa voi päästä lähelle suullista kerrontaa, spontaaniutta, elävyyttä. Aina välillä kuulee, että "olipa tuo saamelainen elokuva", ja olen miettinyt, onko saamelaisessa elokuvakerronnassa jotain erityistä.

Itse olen ajatellut tämän niin, että koska saamelainen maailmankatsomus on syklinen, kuten luonto itse, se näkyy myös taiteessa, elokuvassakin. Voisi ajatella tarinan vaikkapa kehäksi, se vain alkaa jostain, mutta ei välttämättä pääty, vaan kiertää aina takaisin, tarinan sisällä voi olla toinenkin tarina ja kolmaskin... 
On ollut hienoa huomata myös, että saamelaisten elokuvien kirjo on laajentunut, ja tekijät ovat tarttuneet muihinkin aiheisiin kuin saamelaiseen identiteettiin. Vaikka se onkin tärkeä aihe, ja monille elokuvantekijöille myös ensimmäinen aihe.

Saamelaisten aktivistien toiminta on ollut vilkasta viime vuosina, esimerkiksi Jäämeren ratahankkeen vastustajina. Näissä aktuaalisissa aiheissa riittää paljon kaluttavaa elokuvatekijöille, ja dokumenttielokuvan puolella tehdäänkin jo paljon mutta itse näen, että poliittisissa aiheissa olisi ainesta myös fiktiiviselle käsittelylle.

Viime vuosina on käyty paljon keskustelua saamelaisten asemasta Suomessa - onko tällä ollut mielestäsi jotain seurauksia, onko tietoisuus kasvanut?

Etenkin saamelaistaiteilijat ja aktivistit ovat olleet näkyviä viime vuosina, mutta myös valtakulttuurin puolelta on osallistuttu keskusteluun, mikä on tervetullutta. On nähty hyviä avauksia ja tietoisuus on kasvanut, vaikka erityisesti somessa korostuu myös huomion negatiivinen puoli: vihapuheen lisääntyminen.

Mutta saamelaiset ovat tulleet ainakin näkyvämmiksi. Haluan uskoa, että myös hyvää keskustelua ja ymmärrystä on syntynyt puolin ja toisin.

\section{Mitä pohjoinen sinulle merkitsee?}

Ensinnäkin kotia, ei vain fyysistä, vaan myös henkistä, sielun kotia.

Kun asuin etelässä, kului välillä pitkiäkin aikoja, etten päässyt käymään Saamenmaalla. Sitten kun vihdoin saavuin tänne, tuli sellainen tunne, että haluan olla lähellä maata, syleillä sitä. Nyt kun asun pohjoisessa, saan olla koko ajan lähellä Saamenmaata, vaikka Rovaniemi ei kuulukaan siihen, mutta ollessani Utsjoella ja pohjoisessa, missä vietän suurimman osan ajastani.

Minulle pohjoisuuteen kuuluu myös oman kansani oma historia. Se että pohjoisessa voin konkreettisesti tuntea omat esiäidit ihollani. Tämän tunteen haluan tuoda elokuvaankin. Kun on ollut pitkään poissa kotoa ja vihdoin palaa sinne, niin asiat alkavat elää ympärillä, talo tai järvi alkaa puhua.

Pohjoisuuteen liittyy myös hirveästi haavoittuvaisuutta, erityisesti ilmastonmuutoksen vuoksi. Itselleni on tullut voimakas halu suojella ja suojata pohjoisen luontoa. Pohjoisessa on läsnä paitsi historia niin myös tulevaisuus, kysymys siitä miten pohjoisen luonnolle, metsälle ja maalle käy - että pystyykö täällä vielä tulevaisuudessakin elämään ja harjoittamaan vanhoja elinkeinoja. 